\title{
PENGARUH PENGGUNAAN VIDEO PEMBELAJARAN MATERI SEPAK BOLA TERHADAP HASIL BELAJAR PESERTA DIDIK DI SEKOLAH MENENGAH KEJURUAN KESEHATAN KADER BANGSA PALEMBANG
}

\author{
Rendi Alfani ${ }^{1}$, M. Haris Satria ${ }^{2}$ \\ Mahasiswa Universitas Bina Darma ${ }^{1}$, Dosen Universitas Bina Darma ${ }^{2}$ \\ Jalan Jendral Ahmad Yani No. 3 Palembang \\ Sur-el: rendikeriting17@ gmail.com ${ }^{1}$, haris@ binadarma.ac.id ${ }^{2}$
}

Article info

Article history:

Received:10-11-2021

Revised :13-12-2021

Accepted:15-12-2021

Keywords:

Learning Video,

Football

Kata Kunci:

Video Pembelajaran, Sepak Bola

\begin{abstract}
A B S T R A C T
The aim of this research is to find out the significant effect of the use of learning videos on the learning outcomes of students in soccer at Sekolah Menengah Kejuruan Kader Bangsa Palembang. This type of research is experimental with the research design used is One Group Pretest-Posttest Design. The subjects in this study were students of class XI Sekolah Menengah Kejuruan Kader Bangsa Palembang, totaling 22 people who were all female students. From the results of research and data analysis, it can be concluded that the hypothesis Ha can be accepted or tcount > ttable $(30.53>1.721)$. Thus, it can be concluded that there is an effect of the use of learning videos on the learning outcomes of students in football material at Kader Bangsa Palembang.
\end{abstract}

Tujuan yang ingin dicapai dari penelitian ini adalah untuk mengetahui pengaruh yang signifikan penggunaan video pembelajaran terhadap hasil belajar peserta didik materi sepak bola di Sekolah Menengah Kejuruan Kader Bangsa Palembang. Jenis penelitian ini adalah eksperimen dengan desain penelitian yang digunakan adalah One Group Pretest-Posttest Design. Subjek dalam penelitian ini adalah peserta didik kelas XI Sekolah Menengah Kejuruan Kader Bangsa Palembang yang berjumlah 22 Orang yang merupakan peserta didik perempuan semuanya. Dari hasil penelitian dan analisis data, dapat disimpulkan bahwa hipotesis Ha dapat diterima atau thitung > ttabel $(30,53>1,721)$. Dengan demikian dapat disimpulkan bahwa terdapat terdapat pengaruh penggunaan video pembelajaran terhadap hasil belajar peserta didik materi sepak bola di Sekolah Menengah Kejuruan Kader Bangsa Palembang.

Direktorat Riset dan Pengabdian Masyarakat Universitas Bina Darma. 


\section{JURNAL ILMIAH \\ BINA EDUKASI \\ ISSN 1979-8598 E-ISSN: 2655-8378 \\ http://journal.binadarma.ac.id/index.php/jurnalbinaedukasi \\ Vol. 14, No. 2, Desember 2021, 130 - 141}

\section{PENDAHULUAN}

Pendidikan merupakan suatu kebutuhan yang sangat penting dalam kehidupan sehari-hari. Hampir setiap kegiatan yang kita lakukan sangat berkaitan dengan pendidikan. Menurut Slameto (2010) menjelaskan dalam Permendiknas No. 23 Tahun 2006 memberikan arti bahwa pendidikan jasmani olahraga dan kesehatan adalah bagian integral dari pendidikan keseluruhan yang bertujuan untuk mengembangkan aspek kebugaran jasmani ketrampilan gerak, berfikir kritis, ketrampilan sosial, penalaran, stabilitas emosional, moral pola hidup sehat dan pengenalan lingkungan bersih melalui aktivitas jasmani dalam rangka mencapai tujuan pendidikan nasional.

Syarifudin, dkk (2011) menjelaskan bahwa pendidikan juga memiliki sasaran pedagogis, oleh sebab itu pendidikan dirasa kurang lengkap dengan tidak adanya pendidikan jasmani, olahraga dan kesehatan (Penjasorkes), karena gerak sebagai aktivitas jasmani adalah dasar untuk manusia dalam mengenal dunia dan dirinya sendiri yang secara alami berkembang searah dengan perkembangan zaman. Jadi dalam pendidikan sangat berkaitan dengan pembelajaran gerak dasar sebagai bagian dari upaya mencerdaskan bangsa.

Pendidikan Jasmani Olahraga dan Kesehatan merupakan bagian dari pendidikan secara keseluruhan, bertujuan untuk mengembangkan aspek kebugaran jasmani, keterampilan gerak, keterampilan berfikir kritis, keterampilan sosial, penalaran, stabilitas emosional, tindakan moral, aspek pola hidup sehat dan pengenalan lingkungan bersih melalui aktifitas jasmani. Menurut Samsudin (2008) pendidikan jasmani adalah suatu proses pembelajaran melalui aktivitas jasmani yang didesain untuk meningkatkan kebugaran jasmani, mengembangkan keterampilan motorik, pengetahuan dan prilaku hidup sehat dan aktif, sikap sportif, dan kecerdasan emosi. Lingkungan belajar diatur secara seksama untuk meningkatkan pertumbuhan dan perkembangan seluruh ranah, jasmani, psikomotor, kognitif, dan afektif setiap peserta didik.

Pembelajaran Penjasorkes saat ini telah mengalami banyak perubahan, terutama pada saat pandemi seperti ini. Jika pada saat sebelum pandemi pembelajaran lebih banyak menggunakan praktek tatap muka secara langsung. Sedangkan pada saat ini banyak modifikasi pembelajaran yang dilakukan oleh guru, dengan tujuan kegiatan pembelajaran tetap berjalan dan sesuai dengan tujuan pembelajaran itu sendiri. Salah satu cara yang dapat digunakan adalah dengan menggunakan media pembelajaran yang bervariasi.

Pada saat ini banyak sekali sekolah yang melakukan pembelajaran secara dalam jaringan (daring) dan luar jaringan (luring). Hal ini dilakukan sebagai salah satu cara untuk memutus rantai penyeberan virus corona yang saat ini sangat meresahkan. Dalam pembelajaran saat ini banyak dilakukan secara daring dengan memanfaatkan teknologi seperti Handphone (HP) dan laptop 


\section{JURNAL ILMIAH \\ BINA EDUKASI \\ ISSN 1979-8598 E-ISSN: 2655-8378 \\ http://journal.binadarma.ac.id/index.php/jurnalbinaedukasi \\ Vol. 14, No. 2, Desember 2021, 130 - 141}

sebagai sarana pembelajaran. Dengan pembelajaran yang dilakukan secara daring membuat guru harus menggunakan media pembelajaran yang tepat dan sesuai dengan kebutuhan. Menurut Anderson dalam Bambang Warsita (2018) menjelaskan bahawa media dapat dibagi menjadi dua, yaitu yang pertama sebagai alat bantu pembelajaran dan yang kedua sebagai media pembelajaran.

Pemakaian media pembelajaran sebagai salah satu proses pembelajaran dapat memberikan minat dan keinginan yang baru dari peserta didik, (Arsyad, 2007). Dalam situasi pandemi saat ini media pembelajaran yang menggunakan teknologi digital sangat berperan aktif. Salah satunya adalah media pembelajaran audio visual atau penggunaan video sebagai media pembelajaran bagi peserta didik. Penggunaan video sebagai media pembelajaran dapat menguntungkan peserta didik, karena dalam video pembelajaran dapat diputar berulang-ulang untuk memahami materi. Terutama materi pembelajaran Penjasorkes yang sangat membutuhkan ketelitian gerak, sehingga penggunaan video pembelajaran sangat tepat sekali untuk digunakan.

Sekolah Menengah Kejuruan (SMK) Kesehatan Kader Bangsa Palembang merupakan sekolah kesehatan yang memiliki 2 jurusan yaitu keperawatan dan kebidanan. Sekolah Menengah Kejuruan Kesehatan Kader Bangsa Palembang memiliki jumlah peserta didik perempuan yang lebih banyak dibandingkan peserta didik laki-laki. Berdasarkan pengamatan peneliti saat melakukan Praktik Pengalaman Lapangan (PPL) di sekolah ini, ditemui permasalahan dalam pembelajaran olahraga. Permasalahan ini lebih mengarah pada saat pembelajaran yang menekankan pada gerak aktivitas fisik. Contohnya saat pembelajaran praktik olahraga seperti sepak bola. Banyak sekali peserta didik yang belum menguasai teknik dasar sepak bola, hal ini dikarenakan pada saat pembelajaran banyak peserta didik yang tidak terlalu bersemangat saat kegiatan olahraga outdoor. Selain itu karena jumlah peserta didik perempuan lebih dominan, maka banyak yang tidak menyukai olahraga sepak bola sehinga tujuan pembelajaran belum berjalan maksimal.

Dalam perencanaan pembelajaran dijelaskan bahwa salah satu kompetensi dasar pembelajaran olahraga adalah menerapkan dan mempraktikkan salah satu teknik dasar olahraga permainan bola besar untuk menghasilkan koordinasi gerak yang baik seperti contohnya permainan sepak bola. Akan tetapi pada saat pengamatan, banyak sekali peserta didik yang belum menguasai teknik dasar sepak bola seperti passing, dribbling dan shooting. Contohnya saat saya menyuruh untuk mempersiapkan cara menggiring bola satu persatu menggunakan kun, mayoritas peserta didik tidak maksimal dan terkesan terburu-buru sehingga banyak kesalahan.

Muhajir (2007) mengatakan bahwa sepak bola adalah salah satu permainan yang dilakukan dengan cara menyepak/menendang bola, dengan tujuan utamanya adalah untuk memasukkan bola 


\section{JURNAL ILMIAH \\ BINA EDUKASI \\ ISSN 1979-8598 E-ISSN: 2655-8378 \\ http://journal.binadarma.ac.id/index.php/jurnalbinaedukasi \\ Vol. 14, No. 2, Desember 2021, 130 - 141}

kedalam gawang lawan dan diimbangi dengan mempertahankan gawang supaya tidak kemasukkan bola. Dalam permainan sepak bola ada beberapa teknik dasar seperti menendang, menahan bola, menggiring bola dan menembak bola ke gawang atau sasaran. Sepak bola merupakan olahraga yang sangat terkenal dan digemari banyak orang. Di Indonesia sendiri, sepak bola merupakan olahraga nomor satu yang paling banyak dimainkan dan dibicarakan orangorang.

Sepak bola merupakan olahraga yang termasuk dalam permainan bola besar serta terdapat dalam kurikulum pendidikan di Indonesia. Olahraga sepak bola diajarkan mulai dari jenjang Sekolah Dasar (SD), Sekolah Menengah Pertama (SMP), Sekolah Menengah Atas (SMA) hingga perguruan tinggi. Oleh sebab itu, permainan sepak bola harusnya mudah dilakukan bagi peserta didik. Jika ada kesulitan, itupun mungkin hanya beberapa peserta didik yang memang tidak memiliki minat pada sepak bola. Dalam sepak bola dibutuhkan pemahaman gerak dasar agar mudah dalam mempelajarinya. Salah satu cara dalam memahami gerak dasar sepak bola bisa dilakukan dengan melihat video yang dapat diperoleh di internet atau media sosial. Penggunaan video sangat bagus karena dapat diputar berulang-ulang untuk mengidentifikasi gerakan yang dirasa sulit.

Salah satu penelitian yang menggunakan video sebagai pembelajaran adalah dari Nurfaini dan Taufik Hidayat ( 2018) dengan judul "Pengaruh Media Pembelajaran Audiovisual (Video) Terhadap Hasil Belajar Passing Bawah dan Passing Atas Bolavoli (Pada Peserta didik Kelas XI di Sekolah Menengah Atas (SMA) Kemala Bhayangkari 1 Surabaya”. Dari hasil penelitian ini diperoleh adanya pengaruh yang signifikan dengan hasil uji t menunjukkan bahwa aspek pengetahuan adalah $4.972>2.042$ dan nilai signifikan p sebesar $0.00<0.05$, berarti ada pengaruh yang signifikan. Aspek keterampilan passing bawah $5.033>2.042$ dan nilai signifikan p sebesar $0.00<0.05$, berarti ada pengaruh yang signifikan. Aspek keterampilan passing atas $5.510>2.042$ dan nilai signifikan p sebesar $0.00<0.05$. Peningkatan pada aspek pengetahuan sebesar $16 \%$, keterampilan passing bawah sebesar $48 \%$, dan keterampilan passing atas sebesar $10 \%$.

Berdasarkan permasalahan dan penelitian yang relevan di atas, peneliti tertarik untuk melakukan penelitian pada olahraga sepak bola di Sekolah Menengah Kejuruan Kesehatan Kader Bangsa Palembang. Penelitian ini dilakukan dengan tujuan dapat meningkatkan hasil belajar peserta didik pada materi permainan sepak bola. Oleh sebab itu penulis ingin melakukan penelitian dengan judul "Pengaruh Penggunaan Video Pembelajaran Terhadap Hasil Belajar Peserta Didik Materi Sepak Bola di Sekolah Menengah Kejuruan Kader Bangsa Palembang”. 


\section{METODOLOGI PENELITIAN}

\subsection{Jenis Penelitian}

Pada rancangan penelitian ini, pendekatan yang digunakan adalah pendekatan kuantitatif karena dalam penelitian ini menggunakan data-data numerik yang dapat diolah dengan menggunakan metode statistik. Sedangkan jenis penelitian yang digunakan adalah penelitian eksperimen semu (Quasi Eksperiment Design) dengan menggunakan pendekatan kuantitatif.

\subsection{Desain Penelitian}

Desain penelitian yang digunakan dalam penelitian ini adalah One Group Pretest-Posttest Design. Alasan pemilihan pola desain eksperimen ini dilakukan karena sangat erat kaitannya dengan masalah yang diteliti sesuai dengan pendapat dari Sugiyono (2008) pada desain eksperimen ini terdapat pre-test (sebelum diberi perlakuan) dan post test (setelah perlakuan). Dengan demikian hasil perlakuan dapat diketahui lebih akurat, karena dapat membandingkan dengan keadaan sebelum diberi perlakuan dan sesudah diberikn perlakuan. Dari keadaan ini akan mempermudah dan memberikan keterangan secara jelas tentang pengaruh treatment yang diberikan kepada sampel. Paradigma penelitiannya dapat digambarkan sebagai berikut:

$$
\begin{aligned}
& \mathbf{O}_{1}=\text { hasil pengukuran pre-test (sebelum diberi perlakuan) } \\
& \mathbf{O}_{1} \mathbf{X} \mathbf{O}_{2} \\
& \mathbf{O}_{2}=\text { hasil pengukuran post-test (setelah diberi perlakuan) } \\
& \mathbf{X}=\text { Perlakuan }
\end{aligned}
$$

\subsection{Teknik Pengumpulan Data}

\subsubsection{Observasi}

Arikunto (2006) menjelaskan bahwa metode observasi adalah suatu usaha sadar untuk mengumpulkan data yang dilakukan secara sistematis, dengan prosedur yang standar. Observasi digunakan untuk mengamati hasil belajar sepak bola yang telah dilakukan peserta didik Sekolah Menengah Kejuruan Kader Bangsa Palembang. Dari hasil observasi ini kemudian diperoleh data untuk kemudian dijadikan pedoman dan acuan sebagai bahan dalam penelitian ini. 


\subsubsection{Dokumentasi}

Dokumentasi adalah mencari dan mengumpulkan data mengenai hal-hal yang berupa catatan, transkip, buku, surat kabar, majalah, notulen, rapot, agenda dan sebagainya (Arikunto, 2006). Dokumentasi digunakan untuk memperoleh data pada proses pelaksanaan dalam penelitian, dan hasil penelitian. Data ini bisa berupa profil sekolah, nilai peserta didik, foto kegiatan penelitian, serta hasil olah data.

\subsubsection{Tes}

Arikunto (2006) menjelaskan bahwa tes adalah "Serentetan pertanyaan atau latihan serta alat lain yang digunakan untuk mengukur keterampilan, pengetahuan intelegensi, kemampuan atau bakat yang dimiliki oleh individu atau kelompok". Tes yang akan digunakan dalam penelitian ini adalah tes keterampilam bermain sepak bola peserta didik kelas XI Sekolah Menengah Kejuruan Kader Bangsa Palembang.

\subsection{Instrumen}

Instrumen menurut Arikunto (2006) adalah alat atau fasilitas yang digunakan oleh peneliti dalam mengumpulkan data agar pekerjaannya lebih mudah dan hasil yang lebih baik, dalam arti lebih cermat, lengkap, dan sistematis sehingga lebih mudah diolah. Tes yang akan dilakukan dalam penelitian ini adalah kemampuan bermain sepak bola, yaitu tes dribbling yang disesuaikan dengan Kompetensi Dasar peserta didik SMA. Intrumen tes ini akan menggunakan rubrik penilaian yang sesuai dengan rencana pembelajaran (RPP) yang ada di Sekolah Menengah Kejuruan Kader Bangsa Palembang. Berikut instrumen yang disesuaikan dengan RPP di sekolah.

\subsection{Analisi Data}

Analisis data yang digunakan pada penelitian ini adalah menggunakan analisis Uji-t (t-test). Berdasarkan data yang diperoleh, teknik pengolahan data menggunakan uji-t yaitu dengan membandingkan nilai rerata dari hasil pretest - posttest (sebelum dan sesudah perlakuan) dengan sampel yang sama dimaksud untuk mengetahui pengaruh semua variabel bebas terhadap variabel terikat. (Arikunto, 2006). Adapun rumus yang digunakan untuk menghitung hipotesis penelitian adalah sebagai berikut. 


\section{BINA EDUKASI}

ISSN 1979-8598 E-ISSN: 2655-8378

http://journal.binadarma.ac.id/index.php/jurnalbinaedukasi

Vol. 14, No. 2, Desember 2021, 130 - 141

$$
t=\frac{[M D]}{\sqrt{\frac{\sqrt{\sum_{d} 2}}{N(N-1)}}}
$$

Keterangan:

$\mathrm{MD}=$ Mean dari deviasi (d) antara pretest dan posttest

$\Sigma d^{2}=$ Jumlah defiasi kuadrat dari pasangan

$\mathrm{N}$ = Jumlah pasangan subyek

\section{HASIL DAN PEMBAHASAN}

\subsection{Deskripsi Data Tes Awal}

Setelah diperoleh data dari hasil penelitian, kemudian dilakukan analisis data untuk mencari pengaruh video pembelajaran terhadap hasil belajara materi permainan sepakbola dribbling. Berikut ini data hasil tes awal dribbling sepakbola peserta didik di Sekolah Menengah Kejuruan Kader Bangsa Palembang.

Tabel 1. Hasil Tes Awal

\begin{tabular}{cccccc}
\hline \multirow{2}{*}{ No } & Inisial Siswa & $\begin{array}{c}\text { Tes Dribbling } \\
\text { Psikomotor } \\
(\mathbf{5 0 \%})\end{array}$ & $\begin{array}{c}\text { Afektif } \\
\mathbf{( 3 0 \% )}\end{array}$ & $\begin{array}{c}\text { Kognitif } \\
\mathbf{( 2 0 \% )}\end{array}$ & $\begin{array}{c}\text { Nilai } \\
\text { Akhir }\end{array}$ \\
\hline 1 & ABC & 27,5 & 21 & 14 & 62,5 \\
2 & CC & 25 & 22,5 & 15 & 62,5 \\
3 & DY & 27,5 & 19,5 & 13 & 60 \\
4 & DP & 27,5 & 22,5 & 15 & 65 \\
5 & DMA & 32,5 & 21 & 14 & 67,5 \\
6 & DM & 25 & 19,5 & 13 & 57,5 \\
7 & DLS & 25 & 18 & 12 & 55 \\
8 & F & 27,5 & 19,5 & 15 & 62 \\
9 & IM & 27,5 & 21 & 14 & 62,5 \\
10 & JW & 20 & 22,5 & 12 & 54,5 \\
11 & KAS & 22,5 & 19,5 & 13 & 55 \\
12 & LS & 25 & 18 & 14 & 57 \\
13 & M & 25 & 24 & 15 & 64 \\
14 & NZ & 30 & 18 & 11 & 59 \\
15 & NYS & 27,5 & 21 & 15 & 63,5 \\
16 & NAA & 25 & 21 & 15 & 61 \\
17 & PACD & 25 & 21 & 12 & 58 \\
18 & SAO & 20 & 22,5 & 15 & 57,5 \\
19 & Sh & 27,5 & 18 & 15 & 60,5 \\
20 & Sy & 30 & 21 & 12 & 63 \\
21 & TR & 27,5 & 22,5 & 13 & 63 \\
22 & ZA & 27,5 & 21 & 14 & 62,5 \\
\hline & Jumlah & 577,5 & 454,5 & 301 & $\mathbf{1 3 3 3}$ \\
\hline & Rata-rata & 26,25 & 20,659 & 13,68 & $\mathbf{6 0 , 5 9}$ \\
\hline
\end{tabular}


ISSN 1979-8598 E-ISSN: 2655-8378

http://journal.binadarma.ac.id/index.php/jurnalbinaedukasi

Vol. 14, No. 2, Desember 2021, 130 - 141

\begin{tabular}{ccccc}
\hline Nilai Terbesar & 32,5 & 24 & 15 & $\mathbf{6 7 , 5}$ \\
\hline Nilai Terkecil & 20 & 18 & 11 & $\mathbf{5 4 , 5}$ \\
\hline Standar deviasi & 2,96 & 1,72 & 1,28 & $\mathbf{3 , 4 9}$ \\
\hline Modus & 27,5 & 21 & 15 & $\mathbf{6 2 , 5}$ \\
\hline
\end{tabular}

Berdasarkan tes awal yang dilakukan, maka diperoleh data hasil yang diinginkan. Dari data yang telah didapat maka langkah selanjutnya adalah menentukan rentang, banyak kelas, panjang kelas dan kemudian membuat daftar distribusi frekuensi dan diagaram batang.

\subsubsection{Range}

$\mathrm{R}=$ Data terbesar - Data terkecil

$\mathrm{R}=67,5-54,5=\mathbf{1 3}$

\subsubsection{Jumlah kelas}

$$
\begin{aligned}
& \mathrm{K}=1+3,3 \log (\mathrm{n}) \\
& \mathrm{K}=1+3,3 \log (22) \\
& \mathrm{K}=1+4,42 \\
& \mathrm{~K}=5,42 \text { dibulatkan } \mathbf{5}
\end{aligned}
$$

\subsubsection{Panjang kelas (Ci)}

$$
\begin{aligned}
\mathrm{Ci}=\frac{R}{K} \\
\mathrm{Ci}=13: 5=\mathbf{2 , 6}
\end{aligned}
$$

Tabel 2. Distribusi Frekuensi Tes Awal

\begin{tabular}{cccccc}
\hline No & Interval kelas & $\boldsymbol{f}_{\boldsymbol{i}}$ & $\boldsymbol{x}_{\boldsymbol{i}}$ & $\boldsymbol{x}_{\boldsymbol{i}}^{2}$ & $\boldsymbol{f}_{\boldsymbol{i}} \boldsymbol{x}_{\boldsymbol{i}}$ \\
\hline 1 & $54,5-57,1$ & 4 & 55,8 & 3113,64 & 223,2 \\
2 & $57,2-59,8$ & 3 & 58,5 & 3422,25 & 175,5 \\
3 & $59,9-62,5$ & 9 & 61,2 & 3745,44 & 550,8 \\
4 & $62,6-65,2$ & 5 & 63,9 & 4083,21 & 319,5 \\
5 & $65,3-67,9$ & 1 & 66,6 & 4435,56 & 66,6 \\
\hline & Jumlah & $\mathbf{2 2}$ & $\mathbf{3 0 6}$ & $\mathbf{1 8 8 0 0 , 1}$ & $\mathbf{1 3 3 5 , 6}$ \\
\hline
\end{tabular}

Distribusi frekuensi tes awal dribbling sepakbola akan dipaparkan pada tabel diagram batang di bawah ini. 
ISSN 1979-8598 E-ISSN: 2655-8378

http://journal.binadarma.ac.id/index.php/jurnalbinaedukasi

Vol. 14, No. 2, Desember 2021, 130 - 141

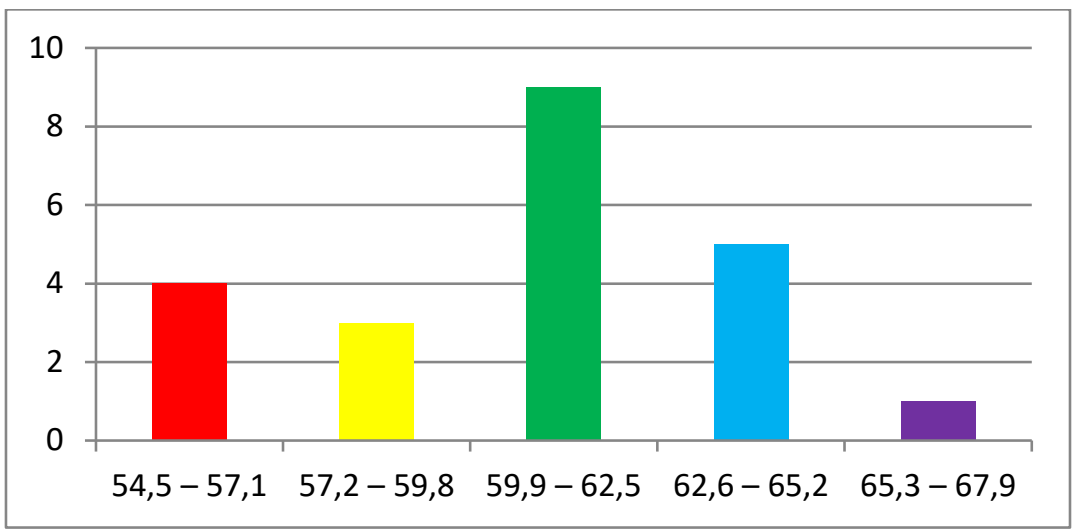

Gambar 1. Diagram Batang Tes Awal

\subsection{Deskripsi Data Tes Akhir}

Setelah diperoleh data dari hasil penelitian, kemudian dilakukan analisis data untuk mencari pengaruh video pembelajaran terhadap hasil belajara materi permainan sepakbola dribbling. Berikut ini data hasil tes akhir dribbling sepakbola peserta didik di Sekolah Menengah Kejuruan Kader Bangsa Palembang.

Tabel 3. Hasil Tes Akhir

\begin{tabular}{|c|c|c|c|c|c|}
\hline \multirow[b]{2}{*}{ No } & \multirow[b]{2}{*}{ Inisisal Siswa } & \multicolumn{3}{|c|}{ Tes Dribbling } & \multirow{2}{*}{$\begin{array}{l}\text { Nilai } \\
\text { Akhir }\end{array}$} \\
\hline & & $\begin{array}{c}\text { Psikomotor } \\
(50 \%)\end{array}$ & $\begin{array}{c}\text { Afektif } \\
(30 \%)\end{array}$ & $\begin{array}{c}\text { Kognitif } \\
(20 \%)\end{array}$ & \\
\hline 1 & $\mathrm{ABC}$ & 32,5 & 21 & 16 & 69,5 \\
\hline 2 & $\mathrm{CC}$ & 30 & 24 & 17 & 71 \\
\hline 3 & DY & 32,5 & 22,5 & 17 & 72 \\
\hline 4 & DP & 30 & 24 & 17 & 71 \\
\hline 5 & DMA & 35 & 21 & 16 & 72 \\
\hline 6 & DM & 30 & 21 & 16 & 67 \\
\hline 7 & DLS & 30 & 19,5 & 17 & 66,5 \\
\hline 8 & $\mathrm{~F}$ & 35 & 19,5 & 17 & 71,5 \\
\hline 9 & IM & 35 & 24 & 16 & 75 \\
\hline 10 & JW & 27,5 & 22,5 & 16 & 66 \\
\hline 11 & KAS & 32,5 & 21 & 17 & 70,5 \\
\hline 12 & $\mathrm{LS}$ & 35 & 21 & 17 & 73 \\
\hline 13 & M & 32,5 & 22,5 & 17 & 72 \\
\hline 14 & NZ & 30 & 19,5 & 15 & 64,5 \\
\hline 15 & NYS & 32,5 & 24 & 17 & 73,5 \\
\hline 16 & NAA & 30 & 21 & 16 & 67 \\
\hline 17 & PACD & 32,5 & 24 & 17 & 73,5 \\
\hline 18 & SAO & 30 & 19,5 & 16 & 65,5 \\
\hline 19 & $\mathrm{Sh}$ & 32,5 & 24 & 17 & 73,5 \\
\hline 20 & Sy & 32,5 & 21 & 17 & 70,5 \\
\hline 21 & TR & 32,5 & 21 & 14 & 67,5 \\
\hline 22 & $\mathrm{ZA}$ & 37,5 & 21 & 17 & 75,5 \\
\hline & Jumlah & 707,5 & 478,5 & 362 & 1548 \\
\hline & Rata-rata & 32,15 & 21,75 & 16,45 & 70,36 \\
\hline
\end{tabular}


ISSN 1979-8598 E-ISSN: 2655-8378

http://journal.binadarma.ac.id/index.php/jurnalbinaedukasi

Vol. 14, No. 2, Desember 2021, 130 - 141

\begin{tabular}{ccccc}
\hline Nilai Terbesar & 37,5 & 24 & 17 & $\mathbf{7 5 , 5}$ \\
\hline Nilai Terkecil & 27,5 & 19,5 & 14 & $\mathbf{6 4 , 5}$ \\
\hline Standar deviasi & 2,35 & 1,65 & 0,8 & $\mathbf{3 , 2 2}$ \\
\hline Modus & 32,5 & 21 & 17 & $\mathbf{7 2}$ \\
\hline
\end{tabular}

Berdasarkan tes akhir yang dilakukan, maka diperoleh data hasil yang diinginkan. Dari data yang telah didapat maka langkah selanjutnya adalah menentukan rentang, banyak kelas, panjang kelas dan kemudian membuat daftar distribusi frekuensi dan diagaram batang

\subsubsection{Range}

$\mathrm{R}=$ Data terbesar - Data terkecil

$\mathrm{R}=75,5-64,5=\mathbf{1 1}$

\subsubsection{Jumlah kelas}

$\mathrm{K}=1+3.3 \log (\mathrm{n})$

$\mathrm{K}=1+3.3 \log (22)$

$\mathrm{K}=1+4,42$

$\mathrm{K}=5,42$ dibulatkan 5

\subsubsection{Panjang kelas $(\mathrm{Ci})$}

$$
\begin{aligned}
\mathrm{Ci} & =\frac{R}{K} \\
\mathrm{Ci} & =11: 5=\mathbf{2 , 2}
\end{aligned}
$$

Tabel 4. Distribusi Frekuensi Tes Akhir

\begin{tabular}{cccccc}
\hline No & Interval kelas & $\boldsymbol{f}_{\boldsymbol{i}}$ & $\boldsymbol{x}_{\boldsymbol{i}}$ & $\boldsymbol{x}_{\boldsymbol{i}}{ }^{2}$ & $\boldsymbol{f}_{\boldsymbol{i}} \boldsymbol{x}_{\boldsymbol{i}}$ \\
\hline 1 & $64,5-66,7$ & 4 & 65,6 & 4303,36 & 262,4 \\
2 & $66,8-69$ & 3 & 67,9 & 4610,41 & 203,7 \\
3 & $69,1-71,3$ & 5 & 70,2 & 4928,04 & 351 \\
4 & $71,4-73,6$ & 8 & 72,5 & 5256,25 & 580 \\
5 & $73,7-75,9$ & 2 & 74,8 & 5595,04 & 149,6 \\
\hline & Jumlah & $\mathbf{2 2}$ & $\mathbf{3 5 1}$ & $\mathbf{2 4 6 9 3 , 1}$ & $\mathbf{1 5 4 6 , 7}$ \\
\hline
\end{tabular}

Distribusi frekuensi tes akhir dribbling sepak bola akan dipaparkan pada tabel diagram batang di bawah ini. 


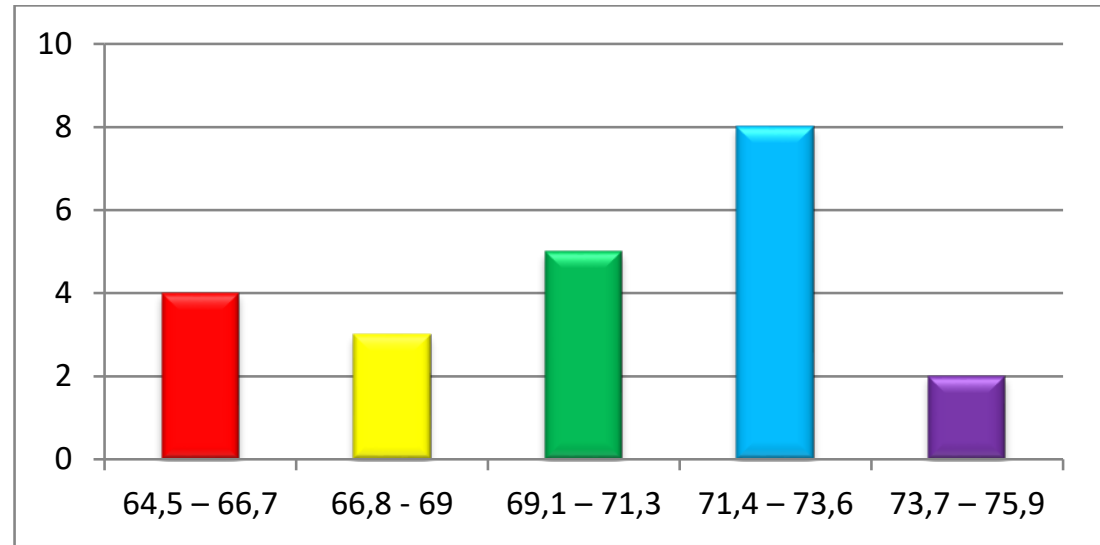

Gambar 2. Diagram Batang Tes Akhir

\section{SIMPULAN}

Dari hasil penelitian dan analisis data, dapat disimpulkan bahwa hipotesis Ha dapat diterima atau $t_{\text {hitung }}>t_{\text {tabel }}(30,53>1,721)$. Dengan demikian dapat disimpulkan bahwa terdapat pengaruh penggunaan video pembelajaran terhadap hasil belajar peserta didik materi sepak bola di Sekolah Menengah Kejuruan Kader Bangsa Palembang.

\section{DAFTAR PUSTAKA}

Arikunto, Suharsimi. (2006). Prosedur Penelitian Suatu Pendekatan Praktik. Jakarta: Rineka Cipta.

Azhar, Arsyad. (2007). Media Pembelajaran. Jakarta: PT Raja Grafindo Persada.

Bambang Warsita. (2018). Teknologi Pembelajaran. Bandung: Rineka cipta.

Muhajir. (2004). Pendidikan Jasmani Teori dan Praktek. Jakarta: Erlangga.

Muhajir. (2007). Berlatih dan Belajar Sepak Bola. Jakarta: Erlangga.

Nurfaini dan Taufik Hidayat (2018). SKRIPSI: Pengaruh Media Pembelajaran Audiovisual (Video) Terhadap Hasil Belajar Passing Bawah dan Passing Atas Bolavoli (Pada Peserta didik Kelas XI di Sekolah Menengah Atas (SMA) Kemala Bhayangkari 1 Surabaya.

Samsudin. (2008). Pembelajaran Pendidikan Jasmani Olahraga dan Kesehatan SD/MI. Jakarta: PT. Prenada Media Group.

Slameto. (2010). Belajar dan Faktor-faktor yang Mempengaruhi. Jakarta: Rineka Cipta. 


\section{JURNAL ILMIAH}

BINA EDUKASI

ISSN 1979-8598 E-ISSN: 2655-8378

http://journal.binadarma.ac.id/index.php/jurnalbinaedukasi

Vol. 14, No. 2, Desember 2021, 130 - 141

Sugiyono. (2008). Penelitian Pendidikan. Bandung: Alfabeta.

Syarifudin, dkk. (2011). Olahraga dan Pendidikan Jasmani Dalam Wajah Keutuhan NKRI. Jakarta: Ardadizya Jaya. 